\title{
"Penggunaan Styrofoam dan Abu Serbuk Kayu pada Campuran Laston Lapis Aus dengan Metode Pencampuran Basah"
}

\author{
Ria Septiani ${ }^{1}$ Sofyan M. Saleh ${ }^{2}$ Lulusi $^{3}$ \\ ${ }^{1}$ Mahasiswa Jurusan Teknik Sipil, Universitas Syiah Kuala, Banda Aceh 23111, Indonesia \\ 2,3 Jurusan Teknik Sipil, Universitas Syiah Kuala, Banda Aceh 23111, Indonesia. \\ Email: riaseptiani21@gmail.com
}

\begin{abstract}
Highways have different characteristics which over time will be damaged. One of the efforts to improve the quality of the mixture of wear-coated asphalt concrete (AC-WC) layer is to modify the asphalt mixture by adding polymeric materials namely styrofoam waste. The purpose of this study was to determine the Marshall Test characteristics from the substitution of the use of styrofoam as substitution for asphalt pen. 60/70 and ash of wood powder as wood powder ash filler against laston layer wear $(A C-W C)$ and to determine the effect of soaking with variations of 30 minutes and 24 hours. The testing method is Marshall testing and durability testing at the optimum bitumen content by using the wet method. The result of this study is optimum asphalt content (KAO) which is $6.50 \%$, the combination of the mixture of wood dust ash and Portland cement is best obtained with a ratio of $25 \%$ ASK and $75 \%$ $P C$ with a KAO value of $6.05 \%$, the highest stability value obtained at $9 \%$ styrofoam variation with KAO $6.50 \%$ which is $1249.01 \mathrm{~kg}$. Durability values in filler combinations did not meet specifications, namely $81.76 \%$ and a combination of styrofoam mixtures with wood powder ash filler and Porland cement were obtained at $96.51 \%$ in accordance with General Specifications of Bina Marga $4^{\text {th }}$ revision in 2018 which is $>90 \%$.
\end{abstract}

Keywords: Asphalt Pen. 60/70, Styrofoam, Wood Powder Ash, Concrete Asphalt Mixture

\begin{abstract}
Abstrak
Jalan raya memiliki karakteristik yang berbeda-beda yang lama-kelamaan akan mengalami kerusakan. Salah satu upaya untuk meningkatkan mutu campuran laston lapis aus (AC-WC) adalah dengan memodifikasi campuran aspal dengan menambahkan bahan polimer yaitu limbah styrofoam. Tujuan dari penelitian ini adalah untuk mengetahui karakteristik Marshall Test dari substitui penggunaan styrofoam sebagai substitusi aspal pen. 60/70 dan abu serbuk kayu sebagai filler abu serbuk kayu terhadap campuran laston lapis aus (AC-WC) dan untuk mengetahui pengaruh rendaman dengan variasi waktu 30 menit dan 24 jam. Metode pengujian yaitu pengujian Marshall dan durabilitas pada kadar aspal optimum terbaik dengan menggunakan metode cara basah. Hasil penelitian diperoleh kadar aspal optimum (KAO) yaitu $6,50 \%$, kombinasi campuran abu serbuk kayu dan semen Portland yang terbaik didapat dengan perbandingan $25 \%$ ASK dan $75 \%$ PC dengan nilai KAO 6,05\%, nilai stabilitas tertinggi didapat pada variasi styrofoam 9\% dengan KAO 6,50\% yaitu $1249,01 \mathrm{~kg}$. Nilai durabilitas pada kombinasi filler tidak memenuhi spesifikasi yaitu sebesar 81,76 \% dan kombinasi campuran styrofoam dengan filler abu serbuk kayu dan semen Portland didapat sebesar 96,51\% sesuai dengan spesifikasi Umum Bina Marga Revisi 4 tahun 2018 yaitu > 90\%.
\end{abstract}

Kata kunci : Aspal Pen. 60/70, Styrofoam, Abu Serbuk Kayu, , Campuran Lapis Aspal Beton

\section{Pendahuluan}

Salah satu prasarana transportasi yang menunjang perkembangan dan untuk meningkatkan perekonomian suatu wilayah ialah jalan raya. Jalan raya yang sering dilalui oleh kendaraan memiliki karakteristik yang berbeda-beda maka lama-kelamaan jalan akan mengalami kerusakan berupa retak maupun bergelombang sebelum umur rencana.

Salah satu cara untuk meningkatkan mutu campuran aspal agar tahan terhadap beban kendaraan adalah dengan memodifikasi campuran aspal dengan menambahkan bahan polimer untuk meningkatkan sifat fisis dan mekanik aspal.

Pada penelitian ini dilakukan modifikasi aspal dengan memanfaatkan limbah plastik yaitu limbah styrofoam sebagai bahan pengganti. Styrofoam biasa dikenal dengan gabus berwarna putih yang digunakan sebagai bahan pengepakan atau pembungkus. Pada penelitian ini digunakan limbah styrofoam hasil pembungkus makanan. Styrofoam memiliki sifat termoplastis, apabila dipanaskan maka styrofoam akan melunak dan kembali mengeras ketika telah dingin. Dengan adanya penggunaan styrofoam sebagai bahan substitusi aspal diharapkan dapat meningkatkan mutu campuran aspal lapis aus (AC-WC).

Pada penelitian terdahulu, bahan pengisi (filler) pada campuran lapis aspal beton biasanya menggunakan fly ash, abu batu, abu sekam padi, lanau sungai, dan kapur. Namun bahan-bahan tersebut susah didapatkan dan relatif mahal. Filler yang digunakan pada penelitian ini abu serbuk kayu. Pemilihan abu serbuk kayu sebagai filler dikarenakan bahan yang tidak sulit didapatkan dan juga harganya yang tidak mahal. Hasil dari pembakarn serbuk kayu akan menghasilkan abu yang meiliki sifat 
sama seperti semen Portland yaitu silika yang berfungsi sebagai bahan pengikat. Dengan memanfaatkan abu serbuk kayu sebagai bahan pengisi dapat mengurangi rongga dan meningkatkan stabilitas campuran lapisan perkerasan.

Adapun tujuan dari penelitian ini adalah untuk mengetahui karakteristik Marshall campuran AC-WC dengan kombinasi penggunaan styrofoam sebagai substitusi aspal dan abu serbuk kayu sebagai filler dengan metode pencampuran basah, meliputi: nilai stabilitas, density, VIM, VFA, VMA, flow, dan Marshall Quotient.

Dari hasil penelitian ini diperoleh kadar aspal optimum (KAO) yaitu 6,05\%. Karakteristik Marshall yang terbaik pada campuran AC-WC dengan substitusi styrofoam dengan variasi $9 \%$ pada KAO 6,50\% dan filler abu serbuk kayu didapat pada $25 \%$ ASK dan $75 \%$ PC. Adapun nilai density $\left(2,43 \mathrm{t} / \mathrm{m}^{3}\right)$, VIM $(4,35 \%)$, VMA $(19,49 \%)$, VFA $(77,75 \%)$, stabilitas $(1249,01 \mathrm{~kg})$, flow (3,13 mm), Marshall Quotient $(399,79 \mathrm{~kg} / \mathrm{mm})$, nilai durabilitas diperoleh yaitu $96,51 \%$ sesuai dengan Spesifikasi 2010 revisi 4 tahun 2018 yaitu $>90 \%$.

\section{Tinjauan Kepustakaan}

\subsection{Lapisan Aspal Beton (Asphalt Concrete, AC)}

Jalan dengan beban lalu lintas yang berat umumnya digunakan beton aspal bergradasi menerus (Sukirman[3]). Lapis aspal beton dibagi menjadi tiga bagian yaitu Laston Lapis Aus (Asphalt ConcreteWearing Course), Laston Lapis Pengikat (Asphalt Concrete-Binder Course), dan Laston Lapis Pondasi AC-Base (Asphalt Concrete-Base). Sifat-sifat campuran lapis aspal beton dapat dilihat pada Tabel 1 berikut:

Tabel 1 Ketentuan Sifat-Sifat Campuran Laston AC

\begin{tabular}{lccc}
\hline \multicolumn{1}{c}{ Sifat-sifat Campuran } & & Laston (AC) & AC-WC Mod \\
\hline Jumlah tumbukan perbidang & & 75 & 75 \\
Rongga dalam campuran (\%) & Min & 3,0 & 3,0 \\
\cline { 2 - 4 } & Maks & 5,0 & 5,0 \\
Rongga dalam agregat (VMA) (\%) & Min & 15 & 15 \\
Rongga terisi aspal (\%) & Min & 65 & 65 \\
Stabilitas Marshall (kg) & Min & 800 & 1000 \\
\cline { 2 - 4 } & Maks & - & - \\
Pelelehan (mm) & Min & 2 & 2 \\
\cline { 2 - 4 } Marshall Quotient (kg/mm) & Maks & 4 & 4 \\
Stabilitas Marshall sisa (\%) setelah & Min & 250 & - \\
perendaman selama 24jam, 60*C & & & \\
Rongga dalam campuran (\%) pada & Min & 2 & \\
kepadatan membal (refusal) & & & \\
\end{tabular}

Sumber: Bina Marga 2010 Revisi 4 (2018)

\subsection{Bahan Campuran Aspal Beton}

\subsubsection{Aspal}

Aspal memiliki sifat termoplastis, yaitu apabila dipanaskan akan mencair dan mengeraskan kembali apabila telah dingin. Pada saat mencair, aspal dapat menyelimuti atau membungkus agregat dalam campuran.

\subsubsection{Styrofoam}

styrofoam merupakan salah satu jenis polimer plastik yang dapat digunakan untuk bahan substitusi aspal. Styrofoam memiliki sifat yang sama seperti aspal yaitu sifat termoplastis. Styrofoam akan menjadi lunak jika dicampur dengan bensin dan dapat berfungsi sebagai perekat.

Aquina[1], telah melakukan penelitian mengenai karakteristik campuran aspal porus dengan substitusi styrofoam pada aspal pen. 60/70. Variasi kombinasi styrofoam yang digunakan adalah 5\%, 7\%, dan $9 \%$. Dari hasil penelitian, variasi styrofoam yang terbaik didapat pada variasi $9 \%$ dengan KAO 6,26\%.

Isnanda[2], juga telah melakukan penelitian mengenai pengaruh substitusi polystyrene (Ps) dan abu arang tempurung kelapa sebagai filler terhadap campuran AC-WC. Variasi kombinasi styrofoam yang digunakan 7\%, 9\%, dan $11 \%$. Dari hasil penelitian, variasi styrofoam yang terbaik didapat pada variasi $11 \%$ dengan KAO 4,70\% yaitu $1497,85 \%$.

\subsubsection{Agregat}

Agregat merupakan batuan dari hasil alam atau buatan yang berupa butir batu pecah, pasir, dan kerikil. Agregat berfungsi sebagai bahan campuran beraspal yang dapat menahan beban pada bagian perkerasan jalan, sehingga mutu agregat sangat berpengaruh terhadap kemampun campuran aspal.

Gradasi agregat diperoleh dari hasil analisa saringan merupakan campuran dari diameter-diameter butiran agregat yang menggunakan satu set saringan, untuk menunjukkan gradasi agregat atau klasifikasi agregat digunakan suatu grafik dalam skala logaritma. Menurut Bukhari, et all.[4], gradasi agregat merupakan gradasi yang saling mengunci akibat adanya distribusi partikel agregat yang dapat mempengaruhi stabilitas perkerasan.

\subsubsection{Bahan Pengisi (Filler)}

Bahan pengisi adalah partikel yang berbutir halus yang mempunyai ukuran partikelnya $<0,075 \mathrm{~mm}$ (lolos saringan No. 200). Filler berfungsi sebagai pengisi antar rongga agregat kasar untuk mengurangi besar rongga, meningkatkan viskositas suatu campuran agregat, dan meningkatkan stabilitas kerapatan.

Semen Portland merupakan hasil dari pencampuran dan pembakaran batu kapur yang berbentuk bubuk berfungsi untuk merekatkan agregatagregat dan mengisi antar rongga udara diantara butir agregat.

Abu serbuk kayu adalah abu yag dihasilkan dari pembakaran serbuk kayu. Pada pembakan serbuk kayu dengan suhu tertentu abu dihasilkan mengandung silika sebagai bahan pengikat dan perekat antar rongga agregat.

Cahya[5], telah melakukan penelitian mengenai pengaruh penggunaan abu serbuk kayu sebagai filler pada campuran pada campuran laston lapis aus (ACWC). Penggunaan variasi abu serbuk kayu dan semen Portland sebagai filler masing-masing sebesar 75\%$25 \%, \quad 50 \%-50 \%, 25 \%-75 \%$, dan $0 \%-100 \%$. Dari 
penelitian, KAO terbaik didapat pada variasi filler $0 \%$ ASK-100\% SP dengan nilai 5,31\%.

\subsubsection{Aspal Modifikasi Polimer}

Pencampuran antara aspal keras dengan suatu bahan tambahan lainnya disebut dengan aspal modifikasi. Persyaratan sifat-sifat fisis aspal modifikasi polimer dapat dilihat pada Tabel 2 berikut.

Tabel 2 Persyaratan Sifat-Sifat Fisis Aspal Modifikasi Polimer

\begin{tabular}{lcc}
\hline \multicolumn{1}{c}{ Sifat-sifat Fisis Aspal } & Standar & Syarat \\
\hline Berat jenis $\left(25^{\circ} \mathrm{C}\right)$ & SNI 06-2441-2011 & $\geq 1,0$ \\
Penetrasi $\left(25^{\circ} \mathrm{C} ; 5\right.$ detik; $\left.0,1 \mathrm{~mm} ; 100 \mathrm{gr}\right)$ & SNI 2456:2011 & $\geq 50$ \\
Daktilitas $\left(25^{\circ} \mathrm{C} ; 5 \mathrm{~cm} /\right.$ detik $)$ & SNI 2432-2011 & $\geq 50$ \\
Titik lembek: ${ }^{\circ} \mathrm{C}$ & SNI 2434-2011 & $\geq 48$ \\
\hline
\end{tabular}

Sumber: Bina Marga 2010 Revisi 4 (2018)

\subsection{Perencanaan Campuran Aspal Beton}

\subsubsection{Gradasi rencana}

Gradasi menerus merupakan gradasi agregat yang digunakan untuk perencanaan campuran laston lapis aus. Spesifikasi gradasi laston lapis aus dapat dilihat pada Tabel 3 berikut:

Tabel 3 Spesifikasi Gradasi Agregat Laston Lapis Aus (AC-WC)

\begin{tabular}{ccc}
\hline \multicolumn{2}{c}{ Ukuran ayakan } & \% Berat yang Lolos \\
\hline ASTM & $(\mathbf{m m})$ & AC-WC \\
\hline $3 / 4 "$ & 19 & 100 \\
$1 / 2 "$ & 12,5 & $90-100$ \\
$3 / 8 "$ & 9,5 & $77-90$ \\
No.4 & 4,75 & $53-69$ \\
No.8 & 2,36 & $33-53$ \\
No.16 & 1,18 & $21-40$ \\
No. 30 & 0,6 & $14-30$ \\
No. 50 & 0,3 & $9-22$ \\
No. 100 & 0,15 & $6-15$ \\
No. 200 & 0,075 & $4-9$ \\
\hline
\end{tabular}

Sumber: Bina Marga 2010 Revisi 4 (2018)

\subsubsection{Kadar Aspal Rencana}

Kadar aspal awal dibutuhkan untuk perencanaan sebelum didapatkan kadar aspal optimum. Nilai kadar aspal rencana $(\mathrm{Pb})$ dapat ditentukan oleh persamaan di bawah ini:

$P_{b}=0,035(\% C A)+0,045(\% F A)+0,18(\%$ Filler $)$

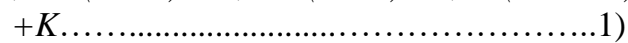

Dimana:

$\mathrm{P}_{\mathrm{b}} \quad=$ kadar aspal tengah

$\mathrm{CA}=$ tertahan saringan No.8;

FA = lolos saringan No.8 dan tertahan saringan No. 200;

Filler = lolos saringan No. 200;

$\mathrm{K}=$ konstanta $0,5-1$ untuk lapis $\mathrm{AC}-\mathrm{WC}$

\section{$2.4 \quad$ Uji Marshall}

Pengujian dengan menggunakan alat Marshall adalah metode campuran yang paling banyak digunakan di Indonesia (Sukirman[6]). Parameter Marshall meliputi, nilai stabilitas, density, rongga dalam campuran (VIM), rongga dalam mineral agregat (VMA), dan rongga terisi aspal (VFA), kelelehan plastis (flow), dan Marshall Quotient.

\section{Metodologi Penelitian}

Penelitian ini dilakukan di Laboratorium Jalan Raya Fakultas Teknik Universitas Syiah Kuala Banda Aceh dan di Laboratorium Material Dinas Pekerjaan Umum dan Penataan Ruang Aceh. Agregat yang digunakan adalah kerikil pecah yang diproduksi di PT. Perdana Dinamika Persada yang berlokasi di Leupung Baleu, Kecamatan Kuta Cot Glie, Kabupaten Aceh Besar. Aspal yang digunakan adalah aspal penetrasi 60/70 produksi PT. Pertamina. Styrofoam yang digunakan adalah salah satu limbah plastik pembungkus makanan yang telah dipotong kecil-kecil untuk pencampuran ke dalam aspal pen. 60/70. Abu serbuk kayu digunakan sebagai filler bersumber dari tempat penggergajian kayu dan yang terdapat di panglong kayu di Jl. Iskandar, Kecamatan Ulee Kareng, Banda Aceh, sedangkan filler yang digunakan adalah semen Portland dikombinasikan dengan abu serbuk kayu merupakan produksi PT. Lafarge Cement Indonesia. Aspal yang digunakan adalah aspal penetrasi $60 / 70$ produksi PT. Pertamina.

\subsection{Variasi Kadar Aspal}

Kadar aspal rencana atau kadar aspal tengah divariasikan menjadi 5 variasi yang memiliki perbedaan $0,5 \%$ di setiap variasinya. Dua kadar aspal di bawah kadar aspal rencana dan dua kadar aspal di atas kadar aspal rencana.

\subsection{Pembuatan dan Pengujian Benda Uji}

Pembuatan benda uji dilakukan dengan diperoleh data untuk mengetahui nilai dari karakteristik campuran laston AC-WC. Cara penentuan KAO dengan metode Marshall dan benda uji substitusi styrofoam dan filler abu serbuk kayu dengan menggunakan metode pencampuran basah dapat dilihat pada Tabel 4 sampai dengan Tabel 7.

\section{Tabel 4 Menentukan Nilai KAO dengan Metode Marshall}

\begin{tabular}{ccc}
\hline KadarAspal Pen 60/70 & Kode Benda Uji & Total \\
\hline $\mathrm{Pb}-1,0 \%$ & $\mathrm{KA}_{011} \mathrm{KA}_{012} \mathrm{KA}_{013}$ & 3 \\
$\mathrm{~Pb}-0,5 \%$ & $\mathrm{KA}_{021} \mathrm{KA}_{022} \mathrm{KA}_{022}$ & 3 \\
$\mathrm{~Pb}$ & $\mathrm{KA}_{031} \mathrm{KA}_{032} \mathrm{KA}_{033}$ & 3 \\
$\mathrm{~Pb}+0,5 \%$ & $\mathrm{KA}_{041} \mathrm{KA}_{042} \mathrm{KA}_{043}$ & 3 \\
$\mathrm{~Pb}+1,0 \%$ & $\mathrm{KA}_{051} \mathrm{KA}_{052} \mathrm{KA}_{053}$ & 3 \\
\hline & Jumlah & $\mathbf{1 5}$
\end{tabular}


Tabel 5 Benda Uji dengan Subtitusi Filler Kombinasi Abu Serbuk Kayu dan Semen Portland

\begin{tabular}{|c|c|c|c|}
\hline $\begin{array}{c}\text { Kombinasi Filler Abu Serbuk } \\
\text { kayu dan Semen Portland }\end{array}$ & Kadar Aspal & Kode Benda Uji & $\begin{array}{l}\text { Jumlah } \\
\text { (Buah) }\end{array}$ \\
\hline \multirow{3}{*}{$25 \%$ PC $: 75 \%$ ASK } & $\mathrm{KAO}_{(\mathrm{Bw})}$ & $\mathrm{P}_{\mathrm{A} 11,} \mathrm{P}_{\mathrm{A} 12,} \mathrm{P}_{\mathrm{A} 13}$ & \multirow{4}{*}{9} \\
\hline & $\mathrm{KAO}$ & $P_{A 21,} P_{A 22}, P_{A 23}$ & \\
\hline & $\mathrm{KAO}_{(\mathrm{At})}$ & $P_{A 31,} P_{A 32}, P_{A 33}$ & \\
\hline \multirow{3}{*}{$50 \%$ PC $: 50 \%$ ASK } & $\mathrm{KAO}_{(\mathrm{Bw})}$ & $\mathrm{T}_{\mathrm{A} 11,} \mathrm{~T}_{\mathrm{A} 12,} \mathrm{~T}_{\mathrm{A} 13}$ & \\
\hline & KAO & $\mathrm{T}_{\mathrm{A} 21,} \mathrm{~T}_{\mathrm{A} 22,} \mathrm{~T}_{\mathrm{A} 23}$ & \multirow{2}{*}{9} \\
\hline & $\mathrm{KAO}_{(\mathrm{At})}$ & $\mathrm{T}_{\mathrm{A} 31,} \mathrm{~T}_{\mathrm{A} 32,} \mathrm{~T}_{\mathrm{A} 33}$ & \\
\hline \multirow{3}{*}{$75 \%$ PC $: 25 \%$ ASK } & $\mathrm{KAO}_{(\mathrm{Bw})}$ & $\mathrm{S}_{\mathrm{A} 11,} \mathrm{~S}_{\mathrm{A} 12,} \mathrm{~S}_{\mathrm{A} 13}$ & \multirow{3}{*}{9} \\
\hline & $\mathrm{KAO}$ & $\mathrm{S}_{\mathrm{A} 21,} \mathrm{~S}_{\mathrm{A} 22,} \mathrm{~S}_{\mathrm{A} 23}$ & \\
\hline & $\mathrm{KAO}_{(\mathrm{At})}$ & $\mathrm{S}_{\mathrm{A} 31,} \mathrm{~S}_{\mathrm{A} 32,} \mathrm{~S}_{\mathrm{A} 33}$ & \\
\hline \multirow{3}{*}{$0 \%$ PC $: 100 \%$ ASK } & $\mathrm{KAO}_{(\mathrm{Bw})}$ & $\mathrm{L}_{\mathrm{A} 11,} \mathrm{~L}_{\mathrm{A} 12,} \mathrm{~L}_{\mathrm{A} 13}$ & \multirow{3}{*}{9} \\
\hline & KAO & $\mathrm{L}_{\mathrm{A} 21,} \mathrm{~L}_{\mathrm{A} 22,} \mathrm{~L}_{\mathrm{A} 23}$ & \\
\hline & $\mathrm{KAO}_{(\mathrm{At})}$ & $\mathrm{L}_{\mathrm{A} 31,} \mathrm{~L}_{\mathrm{A} 32,} \mathrm{~L}_{\mathrm{A} 33}$ & \\
\hline \multicolumn{3}{|c|}{ Jumlah } & 36 \\
\hline
\end{tabular}

Tabel 6 Benda Uji Substitusi Styrofoam dan Filler Abu Serbuk Kayu dengan Menggunakan Metode Pencampuran Basah

\begin{tabular}{|c|c|c|c|}
\hline $\begin{array}{c}\text { Kadar Styrofoam } \\
(\%)\end{array}$ & Kadar Aspal & Kode Benda Uji & Jumlah (Buah) \\
\hline \multirow{4}{*}{$7 \%$} & $\mathrm{KAO}_{(\mathrm{Bw})}$ & $\mathrm{B}_{\mathrm{A} 11}, \mathrm{~B}_{\mathrm{A} 12,} \mathrm{~B}_{\mathrm{A} 13}$ & \multirow{3}{*}{9} \\
\hline & $\mathrm{KAO}$ & $\mathrm{B}_{\mathrm{A} 21,} \mathrm{~B}_{\mathrm{A} 22,} \mathrm{~B}_{\mathrm{A} 23}$ & \\
\hline & $\mathrm{KAO}_{(\mathrm{At})}$ & $\mathrm{B}_{\mathrm{A} 31}, \mathrm{~B}_{\mathrm{A} 32,} \mathrm{~B}_{\mathrm{A} 33}$ & \\
\hline & $\mathrm{KAO}_{(\mathrm{Bw})}$ & $\mathrm{B}_{\mathrm{B} 11,} \mathrm{~B}_{\mathrm{B} 12,} \mathrm{~B}_{\mathrm{B} 13}$ & \multirow{3}{*}{9} \\
\hline \multirow[t]{2}{*}{$9 \%$} & $\mathrm{KAO}$ & $\mathrm{B}_{\mathrm{B} 21,} \mathrm{~B}_{\mathrm{B} 22,} \mathrm{~B}_{\mathrm{B} 23}$ & \\
\hline & $\mathrm{KAO}_{(\mathrm{At})}$ & $\mathrm{B}_{\mathrm{B} 31,} \mathrm{~B}_{\mathrm{B} 32,} \mathrm{~B}_{\mathrm{B} 33}$ & \\
\hline \multirow{3}{*}{$11 \%$} & $\mathrm{KAO}_{(\mathrm{Bw})}$ & $\mathrm{B}_{\mathrm{Cl1}}, \mathrm{B}_{\mathrm{Cl} 2}, \mathrm{~B}_{\mathrm{Cl} 3}$ & \multirow{3}{*}{9} \\
\hline & $\mathrm{KAO}$ & $\mathrm{B}_{\mathrm{C} 21}, \mathrm{~B}_{\mathrm{C} 22,} \mathrm{~B}_{\mathrm{C} 23}$ & \\
\hline & $\mathrm{KAO}_{(\mathrm{At})}$ & $\mathrm{B}_{\mathrm{C} 31}, \mathrm{~B}_{\mathrm{C} 32,}, \mathrm{~B}_{\mathrm{C} 33}$ & \\
\hline
\end{tabular}

Tabel 7 Benda Uji dengan Rendaman 30 Menit dan 24 Jam

\begin{tabular}{lcc}
\hline \multicolumn{1}{c}{ Variasi Benda Uji } & $\begin{array}{r}\text { Jumlah Benda } \\
\text { Uji Rendaman } \\
\text { 30 Menit (Buah) }\end{array}$ & $\begin{array}{c}\text { Junlah Benda Uji } \\
\text { Rendaman 24 Jam } \\
\text { (Buah) }\end{array}$ \\
\hline $\begin{array}{l}\text { Benda uji dengan abu serbuk kayu } \\
\text { dan Semen Porland sebagai filler }\end{array}$ & 3 & 3 \\
$\begin{array}{l}\text { Benda uji substitusi styrofoam dan } \\
\text { filler abu serbuk kayu dengan } \\
\text { menggunakan metode pencampuran } \\
\text { basah }\end{array}$ & 3 & 3 \\
\hline \multicolumn{1}{c}{ Jumlah } & 6 & 6 \\
\hline \multicolumn{1}{c}{ Total Benda Uji } & 12 \\
\hline
\end{tabular}

\section{Hasil dan Pembahasan}

\subsection{Pemeriksaan Gradasi}

Agregat yang didapat tidak dapat digunakan langsung dalam campuran, karena tidak memenuhi spesifikasi gradasi. Pemeriksaan gradasi agregat dilakukan untuk penyesuian gradasi menggunakan analisa saringan. Hasil pemeriksaan gradasi rencana dapat dilihat pada Tabel 8 berikut:
Tabel 8 Pemeriksaan Gradasi Rencana (AC-WC)

\begin{tabular}{cccccc}
\hline \multirow{2}{*}{ Ukuran Saringan } & \multicolumn{4}{c}{ Lapisan Beton Aspal (AC-WC) } \\
\cline { 3 - 6 } Saringan & Ukuran (mm) & Spesifikasi & $\begin{array}{c}\text { Gradasi Uji } \\
\text { Rencana }\end{array}$ & Tertahan & Kumulatif \\
\cline { 3 - 6 } & & 100 & 100.0 & & \\
\hline $3 / 4^{\prime \prime}$ & 19,0 & $90-100$ & 92.2 & 7.8 & 7.82 \\
$12^{\prime \prime}$ & 12,5 & $77-90$ & 86.4 & 5.8 & 13.60 \\
$3 / 8^{\prime \prime}$ & 9,5 & $53-69$ & 64.8 & 21.6 & 35.25 \\
No. 4 & 4,75 & $33-53$ & 43.2 & 21.6 & 56.80 \\
No.8 & 2,36 & $21-40$ & 31.4 & 11.8 & 68.59 \\
No. 16 & 1,18 & $14-30$ & 17.9 & 13.5 & 82.13 \\
No. 30 & 0,60 & $9-22$ & 12.0 & 5.8 & 87.98 \\
No. 50 & 0,30 & 9.0 & & \\
No. 100 & 0,15 & $6-15$ & 8.3 & 3.7 & 91.67 \\
No. 200 & 0,075 & $4-9$ & 6.2 & 2.1 & 93.78 \\
Filler & 0 & 0 & 0 & 21.6 & 35.25 \\
\hline
\end{tabular}

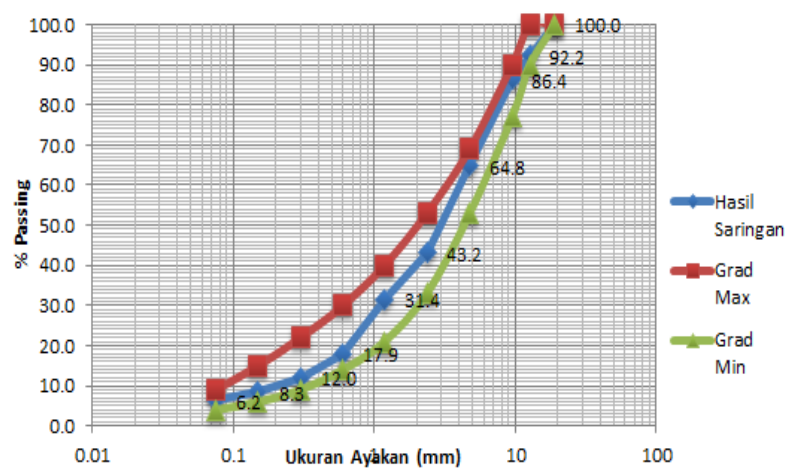

Gambar 1 Grafik Gradasi Rencana Laston (AC-WC)

\subsection{Sifat-Sifat Fisis Aspal}

Pemeriksaan sifat dari fisis aspal meliputi: yaitu pemeriksaan berat jenis, penetrasi, daktilitas, dan titik lembek. Pemeriksaan sifat-sifat fisis aspal penetrasi 60/70 dan pemeriksaan sifat-sifat fisis aspal modifikasi dapat dilihat pada Tabel 9 dan 10.

Tabel 9 Pemeriksaan Sifat-Sifat Fisis Aspal Pen. 60/70

\begin{tabular}{lcccc}
\hline \multicolumn{1}{c}{\begin{tabular}{c} 
Sifat-sifat Fisis \\
\multicolumn{1}{c}{ Aspal }
\end{tabular}} & Standar & Satuan & Syarat & Hasil \\
\hline Berat Jenis & SNI 06-2441-1991 & $\mathrm{gr} / \mathrm{cm}^{3}$ & $\geq 1,0$ & 1,029 \\
Penetrasi & SNI 06-2456-1991 & $(0,1 \mathrm{~mm})$ & $60-70$ & 65 \\
Daktilitas & SNI 06-2432-1991 & $\mathrm{cm}$ & $\geq 100$ & 120 \\
Titik lembek & SNI 06-2434-1991 & ${ }^{\circ} \mathrm{C}$ & $\geq 48$ & 49 \\
\hline
\end{tabular}

Tabel 10 Pemeriksaan Sifat-Sifat Fisis Aspal Modifikasi (Subtitusi Styrofoam)

\begin{tabular}{lccccc}
\hline \multirow{2}{*}{$\begin{array}{c}\text { Sifat-sifat } \\
\text { Fisis Aspal }\end{array}$} & \multirow{5}{*}{ Satuan } & \multicolumn{3}{c}{ Variasi Persentase Kombinasi } \\
\cline { 3 - 5 } & & $\mathbf{7 \%}$ & $\mathbf{9 \%}$ & $\mathbf{1 1 \%}$ & \\
\cline { 2 - 5 } Berat Jenis & - & 1,035 & 1,04 & 1,05 & $\geq 1,0$ \\
Penetrasi & $(0,1 \mathrm{~mm})$ & 60 & 54 & 51 & $\geq 50$ \\
Titik Lembek & ${ }^{\circ} \mathrm{C}$ & 48,5 & 49 & 49,5 & $\geq 48$ \\
Daktilitas & $\mathrm{cm}$ & 120 & 120 & 120 & $\geq 50$ \\
\hline
\end{tabular}




\section{3}

\section{Penentuan Kadar Aspal}

Gradasi perencanaan memiliki sebesar: $\mathrm{Ca}=35,2 \%, \mathrm{Fa}=58,5 \%$, Filler $=6,2 \%$ dan konstanta yang diambil adalah 0,5. Maka kadar aspal tengah sebesar:

$$
\begin{aligned}
\mathrm{Pb} & =0,035(\% \mathrm{CA})+0,045(\% \mathrm{FA})+0,18(\% \text { Filler })+ \\
& \text { Konstanta } \\
= & 0,035(35,2 \%)+0,045(58,5 \%)+0,18(6,2 \%)+ \\
& 0,55 \\
= & 1,232+2,633+1,116+0,55 \\
= & 5,5
\end{aligned}
$$

\subsection{Hasil Pengujian Marshall Untuk Penentuan} Kadar Aspal Optimum

\begin{tabular}{|c|c|c|c|c|c|c|}
\hline \multirow{2}{*}{$\begin{array}{c}\text { Karakteristik } \\
\text { Campuran }\end{array}$} & \multicolumn{5}{|c|}{ Kadar Aspal (\%) } & \multirow{2}{*}{$\begin{array}{l}\text { Spesifikas } \\
\text { BM (2018) }\end{array}$} \\
\hline & 4,5 & 5,0 & 5,5 & 6,0 & 6,5 & \\
\hline Density $\left(\mathrm{tm}^{3}\right)$ & 2,42 & 2,43 & 2,46 & 2,45 & 2,44 & - \\
\hline $\operatorname{VIM}(\%)$ & 7,75 & 6,60 & 4,66 & 4,30 & 4,07 & Min. 3-5 \\
\hline $\operatorname{VMA}(\%)$ & 18,31 & 18,39 & 17,79 & 18,56 & 19,44 & $\operatorname{Min} 15$ \\
\hline VFA $(\%)$ & 57,85 & 64,18 & 74,39 & 76,95 & 79,16 & Min. 65 \\
\hline Stabilitas (kg) & 1157,73 & 1071,68 & 1108,75 & 929,05 & 1002,61 & Min. 800 \\
\hline Flow (mm) & 3,93 & 3,90 & 4,00 & 3,83 & 3,73 & $\operatorname{Min} 2-4$ \\
\hline $\mathrm{MQ}(\mathrm{kg} / \mathrm{mm})$ & 336,90 & 275,65 & 279,14 & 250,77 & 274,44 & $\operatorname{Min} .250$ \\
\hline
\end{tabular}

Didapat dari hasil analisis Marshall dengan kadar aspal sebesar 4,5\%; 5\%; 5,5\%; 6\%; dan 6,5\%. Dapat dilihat pada Tabel. 11 .

\section{Tabel 11 Hasil Pengujian Marshall Untuk Penentuan} KAO

KAO yang diperoleh sebesar $6,05 \%$ yang memenuhi semua spesifikasi parameter Marshall. Nilai KAO tersebut selanjutnya divariasikan menjadi 3 (tiga) kadar aspal dengan range nilai KAO diperoleh lebih kecil dari $1 \%$ maka campuran akan diuji pada batas range bawah, tengah dan batas atas menjadi 5,6\%; $6,05 \%$ dan $6,50 \%$. Grafik penetuan kadar aspal optimum dapat dilihat pada Gambar 2 berikut:

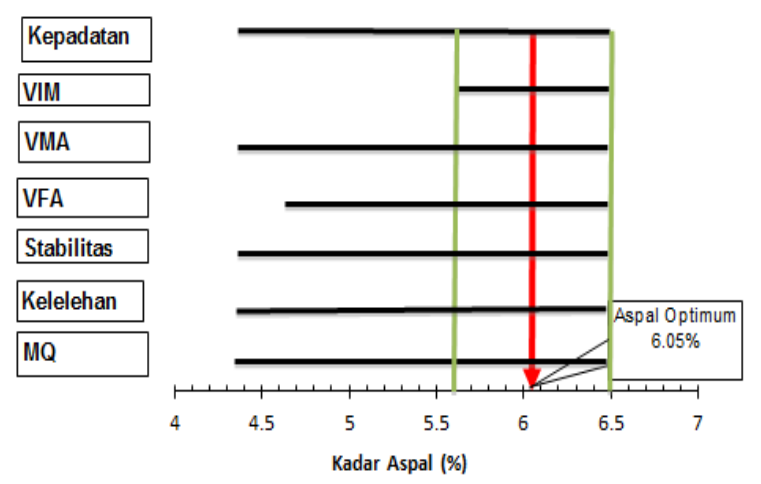

Gambar 2 Grafik Penentuan Kadar Aspal Optimum

\subsection{Pengujian Marshall Kombinasi Filler}

Hasil Rekapitulasi Pengujian Marshall Kombinasi dapat dilihat pada Tabel 12 sampai Tabel 15.
Tabel 12 Hasil Rekapitulasi Pengujian Marshall Kombinasi Filler ASK 25\% dan PC 75\%

\begin{tabular}{ccccl}
\hline Karakteristik & \multicolumn{3}{c}{ Kadar Aspal (\%) } & \multicolumn{1}{c}{ Spesifikasi } \\
Campuran & $\mathbf{5 , 6 0}$ & $\mathbf{6 , 0 5}$ & $\mathbf{6 , 5 0}$ & BM (2018) \\
\hline Density $\left(\mathrm{t} \mathrm{m}^{3}\right)$ & 2,45 & 2,44 & 2,44 & - \\
VIM $(\%)$ & 487 & 4,39 & 3,86 & Min.3-5 \\
VMA (\%) & 18,17 & 18,72 & 19,24 & Min. 15 \\
VFA (\%) & 73,21 & 76,57 & 79,99 & Min. 65 \\
Stabilitas (kg) & 1047,95 & 1129,51 & 1119,14 & Min. 1000 \\
Flow $(\mathrm{mm})$ & 3,33 & 3,87 & 3,93 & Min. $2-4$ \\
MQ (kg $/ \mathrm{mm})$ & 315,86 & 292,80 & 284,85 & Min. 300 \\
\hline
\end{tabular}

Tabel 13 Hasil Rekapitulasi Pengujian Marshall Kombinasi Filler ASK 50\% dan PC 50\%

\begin{tabular}{ccccl}
\hline Karakteristik & \multicolumn{3}{c}{ Kadar Aspal (\%) } & Spesifikasi \\
\cline { 2 - 4 } Campuran & $\mathbf{5 , 6}$ & $\mathbf{6 , 0 5}$ & $\mathbf{6 , 5 0}$ & BM (2018) \\
\hline Density $\left(\mathrm{t} \mathrm{m}^{3}\right)$ & 2,40 & 2,36 & 2,36 & - \\
VIM (\%) & 6,46 & 7,09 & 6,67 & Min.3-5 \\
VMA (\%) & 19,49 & 20,98 & 21,55 & Min. 15 \\
VFA (\%) & 66,91 & 66,29 & 69,10 & Min. 65 \\
Stabilitas (kg) & 1383,23 & 1210,11 & 1180,68 & Min. 1000 \\
Flow (mm) & 3,90 & 4,03 & 3,20 & Min. 2-4 \\
MQ (kg/mm) & 355,69 & 310,12 & 370,08 & Min. 300 \\
\hline
\end{tabular}

Tabel 14 Hasil Rekapitulasi Pengujian Marshall Kombinasi Filler ASK $75 \%$ dan PC 25\%

\begin{tabular}{ccccl}
\hline Karakteristik & \multicolumn{3}{c}{ Kadar Aspal (\%) } & Spesifikasi \\
\cline { 2 - 4 } Campuran & $\mathbf{5 , 6}$ & $\mathbf{6 , 0 5}$ & $\mathbf{6 , 5 0}$ & BM (2018) \\
\hline Density $\left(\mathrm{t} \mathrm{m}^{3}\right)$ & 2,36 & 2,37 & 2.36 & - \\
VIM (\%) & 7,03 & 6,11 & 5,71 & Min. $3-5$ \\
VMA (\%) & 19,86 & 20,01 & 20,60 & Min. 15 \\
VFA (\%) & 64,7 & 69,53 & 72,37 & Min. 65 \\
Stabilitas (kg) & 1452,01 & 1206,43 & 1213,61 & Min. 1000 \\
Flow (mm) & 3,93 & 3,87 & 3,33 & Min. $2-4$ \\
MQ (kg/mm) & 368,93 & 313,35 & 364,95 & Min. 300 \\
\hline
\end{tabular}

Tabel 15 Hasil Rekapitulasi Pengujian Marshall Kombinasi Filler ASK 0\% dan PC 100\%

\begin{tabular}{ccccl}
\hline Karakteristik & \multicolumn{3}{c}{ Kadar Aspal (\%) } & \multicolumn{1}{c}{ Spesifikasi } \\
\cline { 2 - 4 } Campuran & $\mathbf{5 , 6}$ & $\mathbf{6 , 0 5}$ & $\mathbf{6 , 5 0}$ & BM (2018) \\
\hline Density (t/m $\left.{ }^{3}\right)$ & 2,33 & 2,31 & 2,36 & - \\
VIM (\%) & 8,86 & 8,90 & 6,48 & Min.3-5 \\
VMA (\%) & 21,54 & 22,49 & 21,37 & Min. 15 \\
VFA (\%) & 58,86 & 60,48 & 69,72 & Min. 65 \\
Stabilitas (kg) & 1131,17 & 973,15 & 1232,17 & Min. 1000 \\
Flow (mm) & 3,63 & 3,20 & 3,30 & Min. 2-4 \\
MQ (kg/mm) & 312,53 & 303,56 & 375,10 & Min. 300 \\
\hline
\end{tabular}

\section{6}

\section{Hasil Marshall dengan Subtitusi Styrofoam}

Dari hasil pengujian Marshall maka didapatkan nilai parameter Marshall campuran terbaik kombinasi filler abu serbuk kayu dan semen Portland dengan perbandingan 25\% ASK dan 75\% PC yang selanjutnya akan digunakan untuk pengujian Marshall terhadap campuran substitusi styrofoam, dapat dilihat pada Tabel 15 sampai Tabel 17. 
Tabel 16 Pengujian Marshall Subtitusi Styrofoam 7\%

\begin{tabular}{ccccl}
\hline Karakteristik & \multicolumn{3}{c}{ Kadar Aspal (\%) } & \multicolumn{1}{c}{ Spesifikasi } \\
\cline { 2 - 4 } Campuran & $\mathbf{5 , 6 0 \%}$ & $\mathbf{6 , 0 5 \%}$ & $\mathbf{6 , 5 0} \%$ & BM (2018) \\
\hline Density $\left(\mathrm{tm}^{3}\right)$ & 2,41 & 2,42 & 2,42 & - \\
VIM (\%) & 6,28 & 5,29 & 4,57 & Min. 3-5 \\
VMA (\%) & 19,33 & 19,43 & 19,78 & Min. 15 \\
VFA (\%) & 67,51 & 72,79 & 76,98 & Min. 65 \\
Stabilitas (kg) & 1173,32 & 1052,41 & 1075,54 & Min. 1000 \\
Flow $(\mathrm{mm})$ & 3,23 & 4,43 & 4,30 & Min. $2-4$ \\
MQ $(\mathrm{kg} / \mathrm{mm})$ & 363,92 & 237,83 & 253,14 & Min. 300 \\
\hline
\end{tabular}

Tabel 17 Pengujian Marshall Subtitusi Styrofoam 9\%

\begin{tabular}{ccccl}
\hline Karakteristik & \multicolumn{3}{c}{ Kadar Aspal (\%) } & Spesifikasi \\
\cline { 2 - 4 } Campuran & $\mathbf{5 , 6 0 \%}$ & $\mathbf{6 , 0 5} \%$ & $\mathbf{6 , 5 0 \%}$ & BM (2018) \\
\hline Density $\left(\mathrm{t} \mathrm{m}^{3}\right)$ & 2,43 & 2,41 & 2,43 & - \\
VIM (\%) & 5,66 & 5,93 & 4,35 & Min. $3-5$ \\
VMA (\%) & 18,71 & 19,89 & 19,49 & Min. 15 \\
VFA (\%) & 69,73 & 70,18 & 77,55 & Min. 65 \\
Stabilitas (kg) & 1103,02 & 1175,76 & 1249,01 & Min. 1000 \\
Flow (mm) & 3,50 & 3,20 & 3,13 & Min. $2-4$ \\
MQ (kg/mm) & 315,34 & 368,79 & 399,79 & Min. 300 \\
\hline
\end{tabular}

Tabel 18 Pengujian Marshall Subtitusi Styrofoam $11 \%$

\begin{tabular}{ccccl}
\hline Karakteristik & \multicolumn{3}{c}{ Kadar Aspal (\%) } & \multicolumn{1}{c}{ Spesifikasi } \\
\cline { 2 - 4 } Campuran & $\mathbf{5 , 6 0 \%}$ & $\mathbf{6 , 0 5 \%}$ & $\mathbf{6 , 5 0 \%}$ & BM (2018) \\
\hline Density $\left(\mathrm{t} \mathrm{m}^{3}\right)$ & 2,43 & 2,42 & 2,39 & - \\
VIM (\%) & 5,73 & 5,47 & 6,15 & Min. 3-5 \\
VMA (\%) & 18,64 & 19,36 & 20,87 & Min. 15 \\
VFA (\%) & 69,26 & 71,73 & 70,51 & Min. 65 \\
Stabilitas (kg) & 1079,39 & 1149,93 & 1101,14 & Min. 1000 \\
Flow (mm) & 3,63 & 3,83 & 3,70 & Min. 2-4 \\
MQ (kg/mm) & 297,59 & 305,42 & 298,04 & Min. 300 \\
\hline
\end{tabular}

Berdasarkan hasil diatas, pada kombinasi abu serbuk kayu sebagai filler dan substitusi styrofoam diperoleh kombinasi terbaik pada persentase 9\% dengan kadar aspal 6,50\% dan nilai stabilitas $1249,01 \mathrm{~kg}$ telah memenuhi spesifikasi yang disyaratkan oleh Spesifikasi Umum Bina Marga 2010 Revisi 4 (2018).

\subsection{Pengujian Durabilitas}

Berdasarkan pengujian yang telah dilakukan, selanjutnya dilakukan pengujian durabilitas yaitu benda uji pada pengujian Marshall dengan waktu rendaman 30 menit dan 24 jam pada suhu $60{ }^{\circ} \mathrm{C}$. Hasil rekapitulasi pengujian durabilitas dapat dilihat pada Tabel 19 berikut:

Tabel 19 Hasil Rekapitulasi Pengujian Durabilitas

\begin{tabular}{lccc}
\hline Variasi Benda Uji & $\begin{array}{c}\text { Rendaman } \\
\text { 30 Menit }\end{array}$ & $\begin{array}{c}\text { Rendaman } \\
\text { 24 Jam }\end{array}$ & Hasil \\
\hline (a) & (b) & (c) & (d)=c/b \\
\hline $\begin{array}{l}\text { Benda uji dengan abu serbuk kayu dan } \\
\text { semen Portland sebagai filler }\end{array}$ & 1087,17 & 888,87 & $81,76 \%$. \\
$\begin{array}{l}\text { Benda uji dengan substitusi styrofoam } \\
\text { dan filler abu serbuk kayu dengan } \\
\text { menggunakan metode pencampuran } \\
\text { basah }\end{array}$ & 1168,41 & 1127,60 & $96,51 \%$ \\
\hline
\end{tabular}

\subsection{0}

\section{Pembahasan}

Dari hasil tersebut menunjukkan nilai durabilitas untuk campuran beton aspal kombinasi filler abu serbuk kayu yang efektif ini tidak memenuhi syarat spesifikasi yaitu $\geq 90 \%$, nilai yang didapatkan sebesar $81,76 \%$ berarti campuran tidak memiliki nilai nilai keawetan meskipun memiliki stabilitas yang tinggi. Sedangkan pada campuran kombinasi styrofoam $9 \%$ dan filler abu serbuk kayu efektif telah memenuhi syarat spesifikasi dengan nilai $96,51 \%$. Nilai durabilitas pada campuran laston lapis aus (AC-WC) dapat dilihat pada Gambar 3.

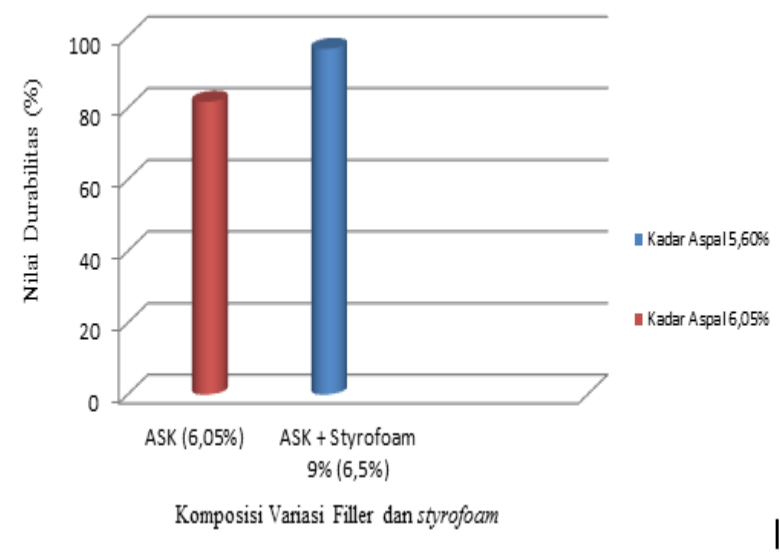

Gambar 3 Hasil Pengujian Durabilitas Benda Uji dengan Filler ASK dan Benda Uji filler dengan Styrofoam 9\%

\section{Kesimpulan}

1. KAO divariasikan menjadi 3 kadar aspal yaitu $5,60 \%, 6,05 \%$, dan 6,50\%. Berdasarkan evaluasi parameter Marshall diperoleh kadar aspal optimum (KAO) 6,05\%.

2. Berdasarkan evaluasi terhadap karakteristik Marshall pada campuran AC- WC dengan variasi persentase abu serbuk kayu dan semen Portland, maka didapatkan persentase $25 \%$ abu serbuk kayu dan $75 \%$ semen Portland sebagai substitusi terbaik, dengan nilai KAO sebesar $6,05 \%$.

3. Nilai stabilitas tertinggi diperoleh pada kadar aspal 6,50\% dengan substitusi kombinasi limbah styrofoam 9\% yaitu sebesar $1249,01 \mathrm{~kg}$. Nilai stabilitas yang diperoleh sebesar $96,51 \%$ telah memenuhi Spesifikasi Umum Bina Marga 2010 Revisi 4. Nilai durabilitas untuk campuran beton aspal kombinasi filler abu serbuk kayu yang efektif tidak memenuhi syarat menurut Spesifikasi Umum Bina Marga 2010 Revisi 4 (2018) yaitu $\geq 90 \%$, nilai yang didapatkan sebesar $81,76 \%$. Pada campuran kombinasi styrofoam dan filler abu serbuk kayu efektif telah memenuhi syarat spesifikasi dengan nilai $96,51 \%$. 


\section{Saran}

1. Dilakukan penelitian dengan subjek yang sama namun variasi bahan tambah yang berbeda.

2. Dilakukakan pengujian reaksi kimia tehadap bahan tambah sehingga dapat mengetahui pengaruh zat tersebut terhadap campuran aspal.

3. Untuk penelitian selanjutnya dapat dilakukan penelitian yang serupa namun menggunakan aspal porus.

\section{Daftar Pustaka}

[1] H. Aquina, S. M. Saleh, dan R. Anggraini, Karakteristik Campuran Aspal Porus dengan Substitusi Styrofoam pada Aspal Penetrasi 60/70. Jurnal Teknik Sipil, Volume 1, Nomor 3, Institut Teknologi Bandung, Bandung, 2014.

[2] Isnanda, S. M. Saleh, dan M. Isya, Pengaruh Substitusi Polystyrene (Ps) dan Abu Arang Tempurung Kelapa sebagai Filler terhadap Karakteristik Campuran AC-WC, Volume 1 Special Issue, Nomor 3, Januari, 2018, Universitas Syiah Kuala, Banda Aceh, 2018.

[3] S. Sukirman, Pekerasan Lentur Jalan Raya, Penerbit Nova, Bandung, 2009.

[4] Bukhari, et all, Rekayasa Bahan dan Tebal Perkerasan, Fakultas Teknik, Universitas Syiah Kuala, Banda Aceh, 2007

[5] C. Y. Cahya, Pengaruh Penggunaan Abu Serbuk Kayu Sebagai Filler Pada Campuran Laston Lapis Aus (AC-WC), Universitas Syiah Kuala, Banda Aceh, 2018.

[6] S. Sukirman, Campuran Beraspal Panas, Penerbit Granit, Bandung, 2003.

[7] Direktorat Jendral Bina Marga, Spesifikasi Umum Direktorat Jenderal Bina Marga Edisi 2010 Revisi 4 Divisi 6, Kementerian Pekerjaan Umum, Jakarta, 2018. 